\title{
Detection of Polio Virus in Municipal Water Bodies of Lahore, Pakistan
}

\author{
Tahir Ahmad, Sadia Zahid, and Muhammad Ashraf
}

\begin{abstract}
The enterovirus and Poliovirus are frequently transmitted through contaminated water or food and encompass a serious threat to public health. The risk of infection is directly allied to inadequate vaccination, poor sanitation and overcrowding. Developing countries like Pakistan are at greater risk because of thickly populated communities along with unplanned sanitation system. Isolation of viruses from large water samples and their subsequent detection has always been challenging. PCR based detection of environmental samples is in frequent use. Major drawback of RT-PCR for direct amplification of the environmental samples is its reduced detection sensitivity due to presence of different naturally occurring organic and inorganic ions which interfere or inhibit the process of amplification. Current methods applied for the removal of these naturally occurring inhibitors involve multistep procedures that are not only costly; they may also result in the loss of virus for subsequent detection procedure. The present study primarily focused on the detection of polio virus in municipal water samples taken from highly populated areas of Lahore. The detection was based on a one step filtration procedure for the concentration of poliovirus from the drinking water and its subsequent application in RT-PCR based assay.
\end{abstract}

Index Terms-Drinking water, filtration, negatively charged membrane, viral RNA, RT-PCR.

\section{INTRODUCTION}

Human emteroviruses belong to family picornaviridae, originally classified into four groups, polioviruses, coxackei A virus, coxsackie B viruses and echoviruses. Enteroviruses can infect millions of people worldwide each year, resulting in broad range of clinical outcomes raging form mild respiratory illness, hand, foot and mouth disease, aseptic meningitis, severe neonatal sepsis like disease, myocarditits and acute flaccid paralysis [1].The enterovirus and Poliovirus are transmitted through water or foods and comprise a serious threat to public health, even when present at very low concentration. The risk of infection is directly correlated with inadequate vaccination, poor hygiene, poor sanitation and overcrowding [2]. Generally, infection occurs in outbreaks during the tropical rainy season and virus gets transmitted via the fecal oral rout through contaminated water [3]. Enteric virus control is very important especially for surface water which is not only used for bathing but also used for drinking purpose. So there must be regular and routine water test for risk assessment [4]. At least 37 different human viruses have been isolated from drinking water all around the world [5].

Manuscript received November 20, 2012; revised January 29, 2013.

Tahir Ahmad, Sadia Zahid and Muhammad Ashraf are with Atta-urRahman School of Applied Biosciences, National University of Sciences and Technology, Islamabad, Pakistan (email: tahir@asab.nust.edu.pk).
Normally viruses can be detected by cell culture techniques but the technique also has some shortcomings, e.g cell culture need high technical demand, great effort, is time consuming appears to takes more than 3 days or some time 6-8 weeks for pathological effects [6]. More sensitive technology and faster methods is now available for the detection of viruses from both environmental and clinical samples. More reliable and efficient method such as PCR and nucleic acid hybridization for the detection of different enteric viruses from water samples are well documented [7][9]. The advantage of PCR over cell culture is due to decreased time and cost and increased sensitivity of RTPCR facilitate the detection of low numbers of target RNAs usually found in environmental samples [10]. Although PCR become the attractive alternative method over cell culture but in environmental samples, organic matter or metal ion causes inhibition of enzymatic amplification. To overcome the inhibitory effects of PCR, different methods of samples treatment have been studied [11].

In recent years, PCR has been adopted extensively in detecting poliovirus in environment owing to its high specificity and simpler operations. Although PCR can pick out even there is only one viruses but its sensitivity still does not come up to the standards for testing virus present in water because the concentrated sample $(10 \mathrm{ml})$ is even still too large for PCR reaction. Testing capability is inconsistent even positive sample can't decide the infectivity of the virus [12]. Researchers have variously described protocols for concentrating viruses form large water samples. A virus concentration method using a negatively charged membrane was developed by Wallis et al [13]), Viruses were adsorbed under $25-50 \mathrm{mM} \mathrm{Mg}^{+2}$ conditions and were eluted using beef extract solution at $\mathrm{pH}$ 9.5. This method was further adapted by using acid instead of $\mathrm{Mg}^{+2}$ [14]. Positively charged membrane method was later described by Sobsey et al. [15]. This method dose not required addition of either $\mathrm{Mg}$ or acid however needed beef extract solution for elution. Use of beef extract facilitates subsequent cultivation with mammalian cell however necessarily has inhibitory effect on PCR detection of the viruses. In this study, we used specific primers from consensus region of VP1-P2A located in the 5' non coding region for the detection of all poliovirus strains [16]. For viral concentration negatively charged membrane filter based adsorption and elution method is used (http://www.aslo.org/books/mave/MAVE_110.pdf).

Purification of RNA is based on viral extraction kits and detection by RT-PCR which is further cloned in TA vector. There were two ain purpose of our study, first, to improve the sensitivity of enteric virus detection by PCR and second by reducing the volume of water concentration and 
removing PCR inhibitory substances

\section{MATERIALS AND METHODS}

\section{A. Sample Collection}

For this study, 135 tap water samples were collected from different areas of Lahore and Islamabad in two liters autoclaved sterilized bottles, $\mathrm{pH}$ and temperature were calculated at the time of sample collection, and samples were stored at room temperature.

\section{B. Virus Concentration Method}

$25 \mathrm{mM} \mathrm{MgCl} 2$ was added in 2 liters of water sample and passed through HA negatively charged membrane (Nihon Millipore) with a $0.45-\mu \mathrm{m}$ pore size and a $90-\mathrm{mm}$ diameter used in a vacuum pump system. Two liters of collected tap water was filtered to absorb the viruses to the membrane, $200 \mathrm{ml}$ of $0.5 \mathrm{mM} \mathrm{H} 2 \mathrm{SO} 4$ was passed through the membrane to rinse out the cations, and then $10 \mathrm{ml}$ of $1 \mathrm{mM}$ $\mathrm{NaOH}$ ( $\mathrm{pH} 10.5$ to 10.8 ) was poured on the membrane and the filtrate was recovered in a tube containing $0.1 \mathrm{ml}$ of 50 $\mathrm{mM} \mathrm{H} 2 \mathrm{SO} 4$ and $0.1 \mathrm{ml}$ of 100x TE buffer for neutralization. The eluted product was further concentrated to a final volume of $2 \mathrm{ml}$. The samples were stored at $-20^{\circ} \mathrm{C}$ until further processing.

\section{Extraction of Viral Nucleic Acid}

Viral RNA extractions were performed by using both conventional phenol-chloroform and commercial RNA/DNA extraction kits (In vitrogen). Biophotometer (Eppendrof, Germany) was used to evaluate the purity and yield of viral RNA extracted by both the methods. The RNA purified was stored at $-80^{\circ} \mathrm{C}$.

\section{Specific Primer Designing}

PCR amplification was carried out by a set of primers $5^{\prime}$ GTCAATGATCACAACCCAC 3'(sense) and 5', AAGAGGTCTCTATTCCACAT 3'(antisense) [4]. These primers amplified a 290 bp VP1 region form poliovirus positive samples. The specificity of these primers were checked against data in NCBI GeneBank using NCBI nt blast.

\section{E. Complementary DNA (CDNA) Synthesis}

The RNA extracted was taken as template for the cDNA synthesis. The reaction mixture contained $10 \mu \mathrm{l}$ RNA template, $10 \mu \mathrm{M}$ gene specific antisense primer and nuclease free water was added to level the volume of reaction to 12 $\mu$ l. This was incubated for 10 minutes at $950 \mathrm{C}$ and then incubated on ice for 5 minutes. Afterwards, 40 units of ReverAid $^{\mathrm{TM}}$ Reverse transcriptase (M-MuLV purchased from Fermentas, USA) along with its buffer (1X) and 20 units of Ribolock RNase inhibitor (Fermentas, USA) were added. Lastly $10 \mathrm{mM}$ dNTPs were added and nuclease free water was used to adjust volume to $20 \mu \mathrm{l}$. This was then incubated in Swift ${ }^{\mathrm{TM}}$ MaxPro Thermal Cycler (Esco, USA) at $42 \mathrm{oC}$ for 90 minutes and then at $95 \mathrm{oC}$ for 5 minutes to inactivate enzymes.

\section{F. $P C R$}

PCR was carried out to amplify VP1 gene of poliovirus. The reaction mixture contained 100ng cDNA template along with $0.5 \mu \mathrm{M}$ gene specific forward and reverse primer, $0.2 \mathrm{mM}$ dNTPs, $0.4 \mathrm{mM} \mathrm{MgCl} 2,5$ units of Taq polymerase (Fermentas, USA) in $25 \mu$ l total reaction volume. PCR was then carried out with 40 cycles of denaturation at $95^{\circ} \mathrm{C}$ for 1 minute, annealing at $64^{\circ} \mathrm{C}$ for 1 minute and elongation at $72^{\circ} \mathrm{C}$ for 1 minute, followed by final extension of 7 minutes in Swift ${ }^{\mathrm{TM}}$ MaxPro Thermal Cycler (Esco, USA). The PCR product was visualized afterwards on $1.5 \%$ agarose gel, stained by ethidium bromide on Wealtec Dolphin Doc (S/N470883) gel documentation system. PCR product was purified from gel by using QIAquick Gel Extraction kit, Qiagen, according to the manufacturer's protocol.

\section{G. Cloning of VP1 Fragment in TA Vector}

The purified $300 \mathrm{bp}$ product was cloned into TA vector using Topo TA Cloning® kit (Catalog no. K4500-01, Invitrogen) according to the manufacturer's protocol. Approximately $150 \mathrm{ng}$ of the PCR product was added to 1 $\mu \mathrm{l}$ of plasmid (5o ng), 5 units of T4 DNA ligase, $1 \mu \mathrm{l}$ of ligase buffer and nuclease free water was added to a final volume of $10 \mu \mathrm{l}$. The mixture was incubated at $14 \mathrm{oC}$ overnight.

Ligation product was Transformed using heat shock method [5]. In brief $50 \mu \mathrm{l}$ competent cells (Top10 strain of Eschersia coli) were incubated on ice for 40 minutes along with $10 \mu$ ligated product. Heat shock was then given at $420 \mathrm{C}$ for 90 seconds and then the mix was transferred to ice and incubated for 5 minute. Luria Bertani (LB) media was then added and the mix was incubated at $37 \mathrm{oC}$ for 2 hours. Cells were then concentrated by short spinning at $4000 \mathrm{rpm}$ for one minute using micro centrifuge. Supernatant was discarded leaving behind $100 \mu \mathrm{l}$ media in which the cells were resuspended and were then spread on agar plate containing $100 \mu \mathrm{g} / \mathrm{ml}$ ampicilin, 20mg/ ml Isopropyl $\beta$-D-1thiogalactopyranoside (IPTG), and $20 \mathrm{mg} / \mathrm{ml}$ of 5- bromo-4chloro-3-indolyl- beta-D-galactopyranoside (Xgal) to obtain blue and white colonies for selection. The plates were incubated overnight at $37 \mathrm{oC}$.

After overnight incubation white colonies were selected from the plate and cultured in $5 \mathrm{ml}$ LB media containing $100 \mu \mathrm{g} / \mathrm{ml}$ ampicilin. These were incubated for around 16 hours (overnight) in Refrigerated Shaking incubator TSS40-250 (Technico Scientific Supply, Pakistan) at 37 oC and $125 \mathrm{rpm}$.

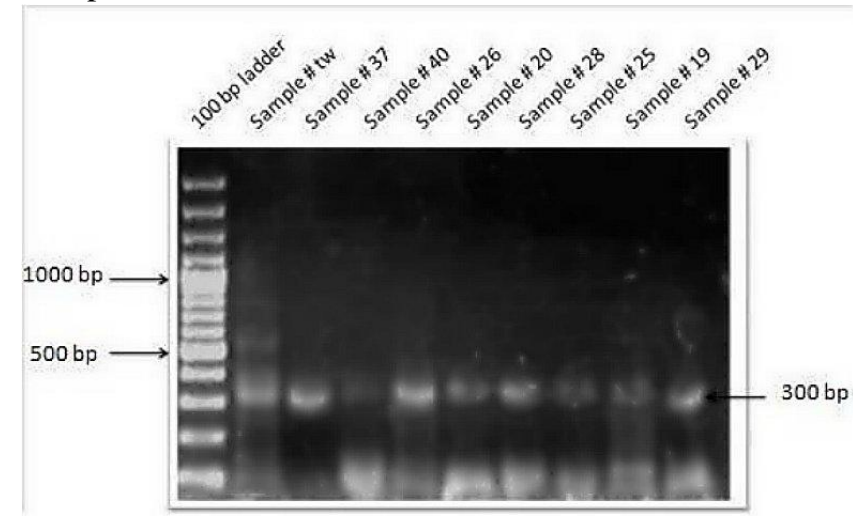

Fig 1. Agrose gel electrophrosis showing Polio virus detection, PCR amplification of VP1 gene from different samples

\section{H. Mini Prep for Plasmid DNA Isolation}

Plasmid DNA was isolated from cultured white clones by using alkaline lysis mini prep protocol described by ${ }^{[3]}$. 
Positive colons were confirmed by restriction digestion of the recombinant plasmid with EcoRI (Fermentas, USA). Approximately 60ng of plasmid was digested using 1 units of the enzyme. Results were visualized on Wealtec Dolphin Doc (S/N470883) gel documentation system and positive clones were selected.

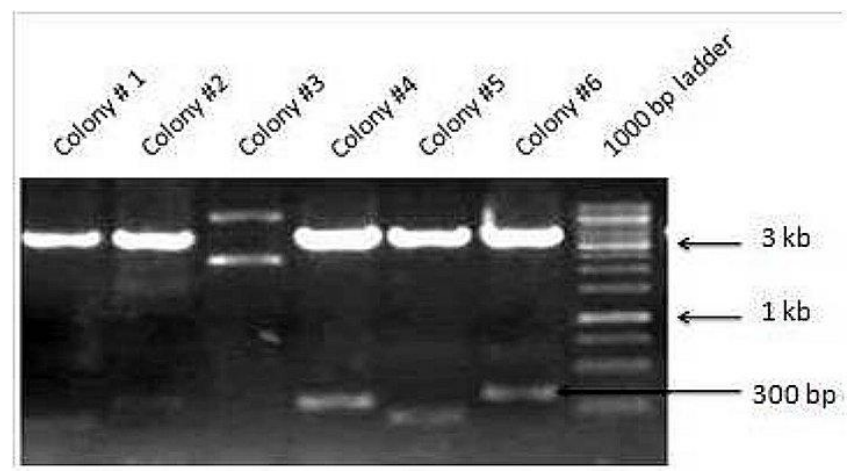

Fig. 2. Agrose gel electrophrosis showing restriction digestion Digestion of TA clone with EcoR1 colony number 2, 4, and 6 are true positive clones

TABLE I: CONCENTRATION OF TOTAL RNA ISOLATED FROM WATER SAMPLES AFTER PASSING FROM NEGATIVELY CHARGED MEMBRANE, TABLE INCLUDES THE DATA OF POLIO POSITIVE SAMPLES ONLY Sample no: $\quad$ RNA Concentration $(\mathrm{ng} / \mu \mathrm{l})$

\begin{tabular}{ll}
\hline 19 & $11 \mathrm{ng} / \mu \mathrm{l}$ \\
24 & $13 \mathrm{ng} / \mu \mathrm{l}$ \\
25 & $5.7 \mathrm{ng} / \mu \mathrm{l}$ \\
27 & $8.66 \mathrm{ng} / \mu \mathrm{l}$ \\
28 & $4.11 \mathrm{ng} / \mu \mathrm{l}$ \\
29 & $9.92 \mathrm{ng} / \mu \mathrm{l}$ \\
\hline
\end{tabular}

\section{RESULTS AND DISCUSSION}

Presently, the common methods for the detection of poliovirus in drinking water samples involve cell culture assay which is expensive and time consuming, it require at least 2 weeks. PCR is an attractive method for the regular monitoring of poliovirus in water samples because of it is more rapid, simpler and less expensive than conventional cell culture method. The concentration of enteroviruses present in water is extremely variable. The copy number of viruses in drinking water are very low, so for the detection of viral RNA, large volumes of water are concentrated into small volume [18]. Normally concentration procedure requires many steps but we use direct concentration of poliovirus from negatively charged membrane filters. After filter elution and re-concentration, extracted RNA was quantified by bio-photometer. The results showed significant efficacy of the negatively charged membrane filter protocol. Subsequent Amplification of the viral genome (VP1) by RT-PCR also confirmed the reliability of the filters used in concentration procedures.

When use direct amplification by RT-PCR to environmental samples reduced detection sensitivity has been observed that might be due to different inhibitors in the form of many naturally occurring organic and inorganic ions which interfere the process of amplification. RNA is very sensitive to other inhibitors like proteases and RNases which may also degraded viral genome resulting in amplification failure leading to false results [19]. To confiscate these substances from the samples PCR inhibitors must be detached or inactivated before the RT-PCR amplification step. Presently many methods have been employed to assess the viral detection but some methods are laborious, costly and involve multiple steps which may result in the loss of virus for subsequent detection procedure. In addition, some organic compound may bind $\mathrm{Mg}$ ion which is essentially required by polymerase enzymes, and may thus interfere in PCR amplification. Many reagents used for the viral RNA extraction can also inhibit PCR [17]. For high quality and high yield of total viral RNA we used both procedure for RNA extraction i.e phenol chloroform and commercial kits, kit protocol was little bit expensive but more accurate reliable and can be completed within an hour (Table I). Some researchers employ heat treatment method for liberating viral genome for PCR detection. However, heat treatment is effective only when the sample is free from inhibitory substances [13]. Those sample which has inhibitory substances, before heat treatment, an extra treatment can be applied by passing the sample through Sephadex and chelex column [21].

In this study consensus primer located in the capsid protein region (PV1) were used for detection, while the antisense primer PV2 located in the conserved region coding for protease $2 \mathrm{~A}$. These primers can amplify a conserved region of the poliovirus present in all the genotypes, vaccine like and wild type poliovirus ${ }^{[4]}$. Positive PCR product shows $290 \mathrm{bp}$ amplification product on $2 \%$ agrose gel electrophoresis when visualized by ethidium bromide staining (Fig. 1). PCR is the rapid and more reliable straightforward screening test for the direct detection of poliovirus from water bodies and the result can be obtained within one day. PCR has an advantage over traditional cell culture because of a high fungal and bacterial count which interferes with cell culture procedures. Cell culture needs more expert handling to avoid contaminations and is a time consuming process.

The part of the PV1 gene amplified by PCR was cloned in TA vector and cloning was confirmed by restriction digestion analysis (Fig. 2). The cloning was further confirmed by sequencing with universal primer and also with PV1 and PV2 specific primer pair. The sequences obtained were compared with those of poliovirus strain submitted in gene data bank (NCBI GeneBank). Out of 35 samples obtained from District Lahore and Rawalpindi, only 9 samples showed presence of wild type poliovirus in drinking water (Fig. 1), clearly indicating that water pipeline might be contaminated with sewage water and poliovirus can spread through this water pipeline into the surrounding communities. We have also applied this method for detection of other viruses from rinking water as well as on waste water samples and found it equally reliable.

In conclusion, the present study focused primarily on the development of the simplified filtration procedure for the concentration of poliovirus from the drinking water and the application of RT- PCR based assay for the rapid and cost effective reliable detection method of medically important 
viruses. This study clearly reflects the over dose polio vaccination and the poor sanitary management in the country. This study can also be expanded to others enteric viruses in environmental and municipal drinking water. This sensitive technology could facilitate researchers to explore the presence of virus in environmental samples and could also be assistance in clinical diagnosis.

\section{ACKNOWLEDGEMENTS}

This study is based upon work funded by Higher Education Commission, Islamabad, Pakistan. Special thanks to Atta-ur-Rahman School of Applied Biosciences for providing and supporting the basic platform for conducting this research.

\section{REFERENCES}

[1] T. S. Momoki, "Surveillance of Enterovirus Infections in Yokohama City from 2004 to 2008," Japanese Journal of Infectious Diseases, vol. 62, pp. 471-473, 2009.

[2] N. Leveque and L. Andreoletti, "A novel mode of transmission for human enterovirus infection is swimming in contaminated seawater: implications in public health and in epidemiological surveillance," Clinical Infectious Diseases, vol. 47, pp. 624, 2008.

[3] L. Kittigul, K. Pombubpa, Y. Taweekate, T. Yeephoo, P. Khamrin, and H. Ushijima, "Molecular characterization of rotaviruses, noroviruses, sapovirus, and adenoviruses in patients with acute gastroenteritis in Thailand," J Med Virol, vol. 81, pp. 345-53, 2009.

[4] J. B. Rose and C. P. Gerba, "Use of risk assessment for development of microbial standards," Water Sci Technol, vol. 24, pp. 29-34, 1991

[5] I. A. Hamza, L. Jurzik, A. Stang, K. Sure, K. Uberla, and M. Wilhelm, "Detection of human viruses in rivers of a densly-populated area in Germany using a virus adsorption elution method optimized for PCR analyses," Water Research, vol. 10, pp. 2657-2668, 2009.

[6] K. A. Reynolds, C. P. Gerba, and I. L. Pepper, "Detection of infectious enteroviruses by an integrated cell cuolture-PCR," Appl Environ Microbiol, vol. 62, pp. 1424-1427, 1996.

[7] M. Abbaszadegan, M. S. Huber, C. P. Gerba, and I. L. Pepper, "Detection of enterioviruses in ground water with polymerase chain reaction," Appl. Environ. Microbiol, vol. 59, pp. 1318-1324, 1993.

[8] R. L. Atmar, T. G. Metcarlf, F. H. Neill, and M. K. Estes, "Detection of enteric viruses in oysters by using the polymerase chian reaction," Appl. Environ. Microbiol, vol. 59, pp. 631- 635, 1993.

[9] J. Wilde and R. Van, "Detection of rotaviruses in the day care environment by reverse transcriptase polymerase chain reaction," $J$ Infect Dis, vol. 166, pp. 507-511, 1992.
[10] J. W. Li and X. W. Wang, "Detection of enteroviruses and hepatitis A virus in water by consensus primer multiplex RT-PCR," World $J$ Gastroenterol, vol. 8, pp. 699-702, 2002.

[11] T. M. Straub, I. L. Pepper, M. Abbaszadegan, and C. P. Gerba, "A method to detect enterovriusesin sewage sludge-amended soil suing the PCR," Appl. Environ Microbiol, vol. 60, pp. 1014- 1017, 1994.

[12] G. Gantzer, S. Senouci, A. Maul, Y. Levi, and L. Schwartzbrodm, "Enterovirus genomes is waste water: concentration on glass wool and glass power and detection by RT-PCR," Virol Method, vol. 65, pp. 265-271, 1997.

[13] C. Wallis and J. L. Melnick, "Concentration of enteroviruses on membrane filters," J. Virol, vol. 1, pp. 472-77, 1967.

[14] M. D. Sobsey, C. Wallis, M. Hendersen, and J. L. Melnick, "Concentration of enteroviruses from large volumes of water," Appl. Microbiol, vol. 26, pp. 529-534, 1973.

[15] M. D. Sobsey, and B. L. Jones, "Concentration of poliovirus from tap water using positively charged microporous filters," Appl. Environ. Microbiol, vol. 37, pp. 588-59, 1997.

[16] C. Chezzi, "Rapid diagnosis of poliovirus infections by PCR amplification," J Clin Microbiol, vol. 34, pp. 1722-5, 1996.

[17] A. Froger and J. E. Hall, "Transformation of Plasmid DNA into E. coli Using the Heat Shock Method," J Vis Exp, vol. 6, pp. 253, 2007.

[18] J. Liu and Q. Wu, "Development of a virus concentration method and its application for thedetection of noroviruses in drinking water in China," J Microbiol, vol. 45, pp. 48-52, 2007.

[19] Y. S. C. Shieh, D. Wait, L. Tai, and M. D. Sobsey, "Methods to remove inhibitors in sewage and other fecal wastes for enterovirus detection by the polymerase chain reaction," J Virol Methods, vol. 54, pp. 51-66, 1995.

[20] L. Rossen, P. Norskov, K. Holmstrom, and O. F. Rasmussen, "Inhibition of PCR by components of food samples, microbial diagnostic assays and DNA-extraction solutions" Int $J$ Food Microbiol, vol. 17, pp. 37-45, 1992.

[21] J. F. Ma, C. P. Gerba, and I. L. Pepper, "Increased sensitivity of poliovirus detection in tapwater concentrates by reverse transcriptasepolymerase chain reaction," J Virol Methods, vol. 55, pp. 295- 302, 1995.

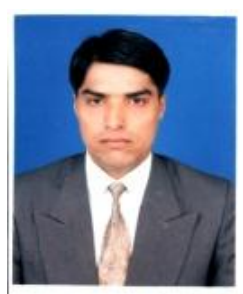

Tahir Ahmad was born on 5 July, 1973 in Abbottabad, Pakistan. He got his M. Phil 2003 , GCU, Lahore, Pakistan. His is the lecturer in Attaur-Rahman School of Applied Biosciences, National University of Sciences and Technology, Islamabad, Pakistan. His field of specialization is Environmental Virology.

$\mathrm{He}$ is regular faculty member of Atta-urRahman School of Biosciences (ASAB), National University of Sciences and Technology, Islamabad, Pakistan. He is actively involved in teaching and research under industrial biotechnology group, since 2008 . 